\title{
The Diverse Cytotoxicity Evaluation of Lactobacillus Discovered from Sheep Milk
}

\author{
Abhinandan Patil ${ }^{1 *}$, Vijay Mali ${ }^{2}$ and Atharv Mali ${ }^{1}$ \\ ${ }^{1}$ School of Pharmaceutical Science, Sanjay Ghodawat University, Kolhapur, India \\ ${ }^{2}$ NICE Advanced Neonatal Care Centre and Children Clinic, Kolhapur, India \\ *Corresponding Author: Abhinandan Patil, School of Pharmaceutical Sciences, \\ Sanjay Ghodawat University, Kolhapur, India.
}

Received: November 22, 2021

Published: November 30, 2021

(C) All rights are reserved by Abhinandan

Patil., et al.
Keywords: Lactobacillus; probiotics; assay; MTT

\section{Abbreviations}

LAB: Lactobacillus; Lp: Lactobacillus plantarum; Lr: Lactobacillus rhamnosus; La: Lactobacillus acidophilus

The pharmacology research, for the evaluation of the toxicity, is become vital in regards to the neutraceuticals products development $[1,7-10]$. The cytotoxicity studies of the nutraceutical products, especially the lactobacillus (LAB) formulation are gaining importance due to its industrial application [11,12]. The interaction of the probiotics cells with the living host cells may rarely precipitate toxicity $[1-3,13,14,17,18]$. The interaction of the LAB in pathophysiological conditions such as cancer is gaining importance as an alternative source of functional food [14-16].

To support the claim MTT test was performed on three different strains of Lactobacillus i.e., Lp- Lactobacillus plantarum: Lr- Lactobacillus rhamnosus and La- Lactobacillus acidophilus. The culture of Lp and La were discovered by our team from sheep milk and whole genome sequence was deposited in NCBI database with reference number- PYBS00000000 and PYBS01000000 respectively $[5,6]$.

In this test, the MTT (3-[4,5-dimethylthiazol-2-yl]-2,5 diphenyl tetrazolium bromide) was used [4]. This reagent passes through the viable cells and enters the mitochondria, producing the dark blue/purple insoluble compound called as formazan. This is observed only in viable cells, as the yellow tetrazolium salt from MTT reagent is reduced to colored purple dye only in the living cells. These viable colored cells get homogenized and soluble because of the use of organic solvent like isopropanol resulting in the formation of the formazan. This complex-colored compound is measured by the spectrophotometric method. The dead cells never show these activities thus, this assay gives the count of the living cells in the form of the viability count and determines the number of metabolically active cells.

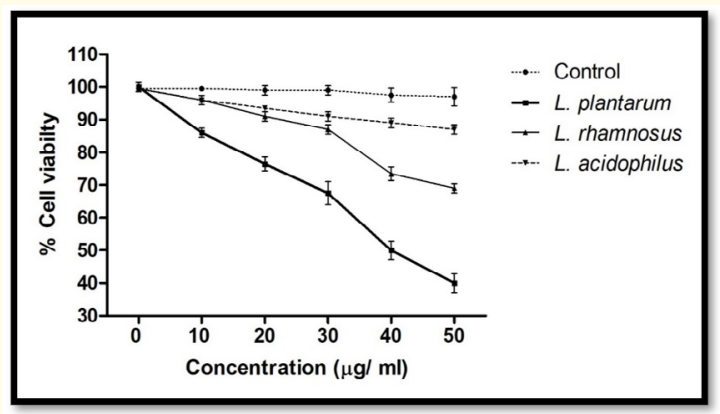

Figure 1: Effects of the cell-free lyophilized filtrate of LAB on the viability of HCT 115 cell line for various concentration by MTT assay. Values are expressed as viability mean ratio $\pm \mathrm{SD}^{*}$, $\mathrm{n}=3$.

The viability study conducted by MTT assay on HCT 115 cell lines shows a decrease in percentage cell viability, an approximately around $40 \%$ in case of the Lp for its highest dose of $50 \mu \mathrm{g} /$ $\mathrm{ml}$ and further, showing the strongest anti-proliferative activity as compared to control group. In the case of Lp, expect the dose of 10 $\mu \mathrm{g} / \mathrm{ml}$ the other doses from $20 \mu \mathrm{g} / \mathrm{ml}$ to $50 \mu \mathrm{g} / \mathrm{ml}$ shows the antiproliferative activity. Similarly, the cell viability results obtained 
in case of Lr, and La are $74 \%$ and $88 \%$ on HCT 115 cell line for its highest dose of $50 \mu \mathrm{g} / \mathrm{ml}$ with respect to the control group. La, which is used as the reference control group, not show any antiproliferative activity.

\section{Bibliography}

1. Abhinandan Patil and Pawar S. "Health benefits of Probiotics by Antioxidant Activity: A review”. Pharma Times 50.9 (2018): $1-3$.

2. Abhinandan Patil., et al. "Granules of unistrain lactobacillus as nutraceutical antioxidant agent" 9.4 (2017): 1594-1599.

3. Disouza J and Patil A. "Antioxidant study and phenolic content of Caralluma fimbriata herb". World Journal of Pharmaceutical Research 3.7 (2014): 565-575.

4. Hamada S., et al. "Evaluation of the rodent micronucleus assay by a 28-day treatment protocol: Summary of the 13th Collaborative Study by the Collaborative Study Group for the Micronucleus Test (CSGMT)/Environmental Mutagen Society of Japan (JEMS)-Mammalian Mutagenicity Study Group (MMS)". Environmental and Molecular Mutagenesis 37.2 (2001): 93110.

5. Patil A and Disouza J. "Genomic-Based Restriction Enzyme Selection for Specific Detection of Lactobacillus rhamnosus and Lactobacillus plantarum strain by $16 \mathrm{~S}$ rDNA PCR-RFLP". International Journal of Innovative Science, Engineering and Technology 1.1 (2020): 91-99.

6. Patil A., et al. "Shelf-life stability of encapsulated lactic acid bacteria isolated from Sheep milk thrived in different milk as natural media". Small Ruminant Research 170 (2019): 19-25.

7. Patil A., et al. "Evaluation of Lactobacillus plantarum growth in milk of Indian buffalo breeds based on its physico-chemical content". Buffalo Bulletin 38.2 (2019): 345-352.

8. Patil A., et al. "Probiotic potential of Lactobacillus plantarum with the cell adhesion properties". Journal of Global Pharma Technology 10.12 (2018): 1-6.

9. Patil A., et al. "Complete Genome Sequence of Lactobacillus plantarum Strain JDARSH, Isolated from Sheep Milk". Microbiology Resource Announcements 9.2 (2020).

10. Patil A., et al. "Banana fibers camouflaging as a gut worm in a 6-month-old infant". Iberoamerican Journal of Medicine 3 (2020): 245-247.
11. Patil AR. "Lactobacillus rhamnosus ARJD as a Functional Food with Potential Antioxidant and Antibacterial Abilities". Acta Scientific Pharmaceutical Sciences 3 (2019): 63-70.

12. Patil AR. "Use of Probiotics as a Functional Food against Cancer". Acta Scientific Pharmaceutical Sciences 3.8 (2019): 103105.

13. Patil AR. "The role of the food and fertilizers in antimicrobial resistance in human and its preventive measures". International Journal of Innovative Science, Engineering and Technology 1.1 (2020): 31-37.

14. Patil AR. "The origin of novel coronavirus: COVID-19". International Journal of Innovative Science, Engineering and Technology 1.1 (2020): 18-23.

15. Patil AR., et al. "Nanotechnology based upgradation in tuberculosis diagnosis and treatment" (2020): 395-414.

16. Patil AR and Disouza J. "Isolation and characterisation of Lactobacillus species from sheep milk". International Journal of Innovative Science Engineering and Technology 1.1 (2020): 9-17.

17. Patil AR and Patil P. "The Insight of Body's Immune System, Inflammation and Damages in Wound Healing- The review". International Journal for Research in Applied Science and Engineering Technology 9.8 (2021): 2777-2780.

18. Patil AR., et al. "Lactobacillus Model Moiety a New Era Dosage Form as Nutraceuticals and Therapeutic Mediator". In Biotechnology and Bio forensics Springer, Singapore (2015): 11-21.

\section{Volume 5 Issue 12 December 2021 (c) All rights are reserved by Abhinandan Patil., et al.}

